Article

\title{
Major Strike-Slip Faults Identified Using Satellite Data in Central Borneo, SE Asia
}

\author{
Afroz Ahmad Shah ${ }^{1, *(1)}$, Mohd Noor Zhafri ${ }^{1}$, Jumat Delson ${ }^{1}$ and Batmanathan Navakanesh ${ }^{2}$ \\ 1 Departmet of Physical and Geological Sciences, Universiti of Brunei Darussalam, Gadong BE1410, Brunei; \\ kzafry83@gmail.com (M.N.Z.); 12b8385@ubd.edu.bn (J.D.) \\ 2 Department of Applied Geology, Curtin University Sarawak, Miri 98009, Malaysia; \\ batmanathannavakanesh@gmail.com \\ * Correspondence: afroz.shah@ubd.edu.bn; Tel.: +673-837-0102
}

Received: 27 February 2018; Accepted: 25 April 2018; Published: 27 April 2018

\begin{abstract}
We use freely available Google satellite data, instrumental seismicity, fault plane solutions, and previously mapped structural and geological maps to identify new fault zones in central Borneo. We have mapped a number of $\sim$ NW-SE trending dextral strike-slip faults and $\sim$ NE-SW to $\sim$ N-S trending sinistral strike-slip fault zones. The geomorphic expression of faulting is shown by the well-developed triangular facets, fault rupture scarps, truncated sedimentary beds, topographic breaks, displaced ridges, deflected streams, faulted Plio-Pleistocene volcanic deposits, and back-tilted Holocene to Recent sedimentary deposits. Some of the mapped faults are actively growing, and show text-book examples of dextral and sinistral offset, which ranges from $\sim 450 \mathrm{~m}$ to tens of $\mathrm{km}$. The dextral strike-slip fault systems are clearly developed in the central and eastern portions of Borneo where they cut through the folded sedimentary sequences for $>220 \mathrm{~km}$. The $\sim \mathrm{NE}-\mathrm{SW}$ to $\sim$ N-S trending sinistral strike-slip faults are dominantly developed in the eastern portion of central Borneo for $>230 \mathrm{~km}$. The geomorphic expression of faulting is clear and the fault scarps are $\sim \mathrm{SE}$ facing for the sinistral fault system, and $\sim \mathrm{NE}$ facing for the dextral fault system. The age of the faulting is constrained by the cross-cutting relationship where the fault cuts through Plio-Pleistocene volcanic deposits for $>30 \mathrm{~km}$, which suggests a neotectonic nature of faulting. The strike-slip fault systems that we have mapped here provide the first geomorphic evidence of large-scale strike-slip faulting in Borneo and suggest the presence of a major sinistral strike-slip fault that runs for $>900 \mathrm{~km}$ through the center of Borneo, and forms a backbone onto which most of the mapped structures root. The mapped structures clearly suggest that plate tectonic forces dominantly control the geological structures that we have mapped and support the regional oblique convergence that is oblique with respect to the major trend of the Crocker Range, which forms the spine of the Borneo Island.
\end{abstract}

Keywords: Borneo; tectonics; strike-slip fault; Sarawak; Sunda block

\section{Introduction}

Fifteen years ago, the bulk of the geological setting of Borneo Island was poorly known because of inaccessibility to its dense tropical rainforest. This has changed with the advancement of technology, particularly with the freely available satellite data which provide a digital platform to conduct geological studies in the region [1-15]. A great variety of satellite data and high-resolution satellite imagery enable geologic, geomorphic, and tectonics investigators to acquire such data over smaller or large areas and gain a more comprehensive understanding of the Earth's dynamic nature of landforms [16]. This methodology reduces the limitations of traditional geological mapping in an area that is politically complex or inaccessible [17-19]. The thick cover of rainforests throughout the regions in Borneo makes it difficult to map it by using high-resolution images, and thus the freely 
available Google terrain view provides a much better platform to map geomorphic landforms on a scale significant to our work (e.g., [14,15,19-27]). The study area occupies the central and eastern portion of the island (Figures 1 and 2), which has not been explored previously at a large scale, as is done here [17]. It lies south of previously mapped regional faults zones (e.g., Baram Line and Tinjar Line), which have not been mapped onshore [28-30]. These lines are considered as the key elements in shaping the geological and tectonic evolution of Borneo Island [31]; however, little work has been done to trace the extent of such "lines" on land (Figure 2). The role of these lines in the shaping of the architecture of Borneo Island thus remains largely unknown [30], and below we have tried to resolve this problem to some extent by mapping large scale faults on land.
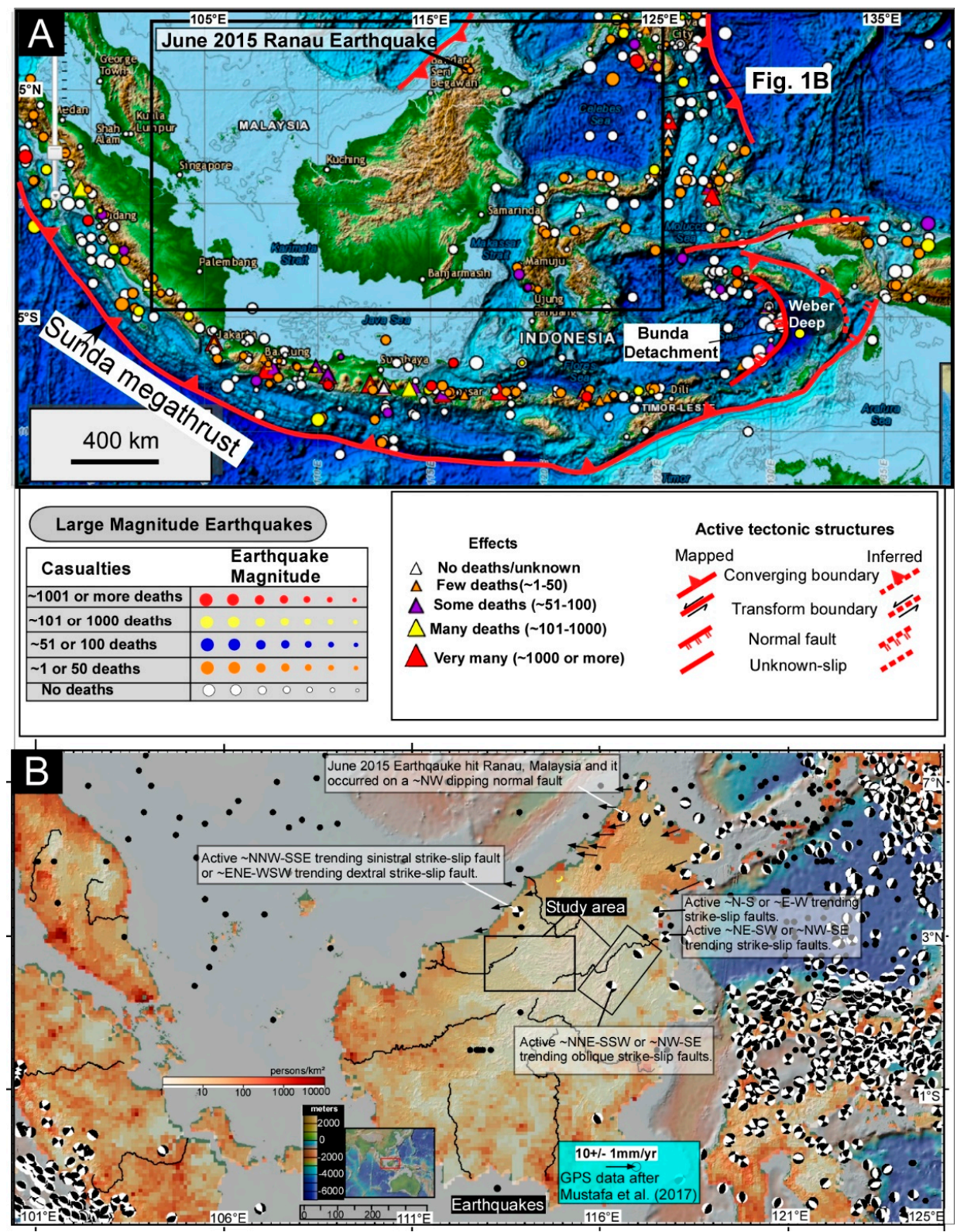

Figure 1. (A) The regional tectonic setting of Borneo, and the location of significant earthquakes and volcanoes in the region. (B) The available earthquake fault plane solutions that are plotted on the satellite image. The earthquakes around the study area are mostly strike-slip. The world population data are plotted on the satellite image and it highlights the pockets of dense population and their vulnerability to earthquake hazards. Map is created in GeoMap App. 


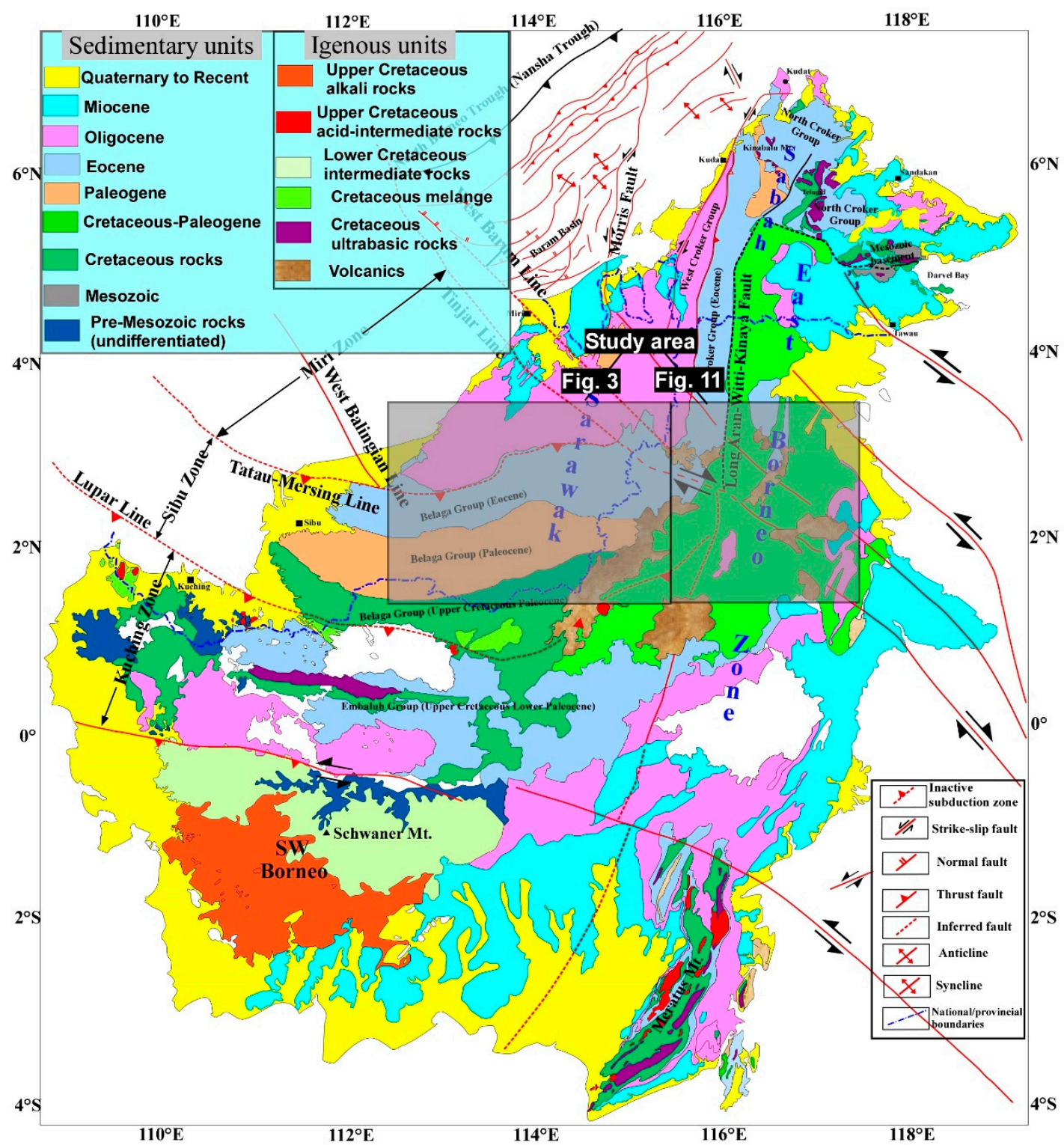

Figure 2. Geological and structural setting of Borneo (modified after [14]). The rectangles show the location of the study area.

Furthermore, although Borneo is located away from major plate boundaries, there are indications of ongoing deformation [32], as shown by the occurrence of earthquakes in the region, mostly on the NW portions of the island $[15,17,18,32]$. The recent earthquake that occurred in Sabah, a region located in the northern part of Borneo, has truly shaken the SE Asian population because it was not expected to happen. A significant number of researchers were equally surprised because of the damage it caused. The medium-sized magnitude earthquake struck Sabah on 5 June 2015 (Figure 1A), and this event is regarded as the biggest recorded earthquake in the history of the region, and it is reported that 18 people lost their lives [15]. Thus, our motivation is to improve what is known about the geological structures of the study region via mapping of the geomorphic features on a regional scale by using the freely available satellite data. This will be the first such large scale structural mapping in the region, and the aim is to build a better structural framework of Borneo, and to relate the mapped structures to the regional tectonics and to understand the gravity versus tectonic deformation of the region: what causes the occurrence of active normal faulting in NW Borneo and thrust and fold belt offshore Sabah 
(Figures 1 and 2) is largely unclear (e.g., [15]), and previous models have called for both gravitational and tectonic forces (e.g., [15]).

\section{Regional Tectonic Setting}

Borneo is part of the Sunda plate, and it is caged by the Phillippine sea plate and the Indo-Australian plate $[1,3,31,33]$. The entire Island is oriented $\sim \mathrm{NE}-\mathrm{SW}$ in contrast to the western portions of the Sunda plate which are oriented NW-SE (Figure 1A). Previous studies have offered some explanation for this, and it is suggested that Borneo Island has rotated in a counter-clockwise motion, which possibly started somewhere in the Mesozoic ( 65 Ma) and it is still active $[3,9,10,34]$. The regional geological map (Figure 2) shows the older rock outcrops are mostly exposed in the eastern portions of the island and the relatively younger rocks dominantly occupy the western portions (Figure 2). The presence of ophiolites in the NW portions of the island possibly suggests a SE-directed subduction zone, which has led to the formation of the present-day suture zone [30]. The $\sim \mathrm{NW}$ verging thrusts belt along which ophiolites are exposed probably reflects the $\sim$ NE-SW trend of the subduction zone. A number of these ophiolite outcrops are mapped in the eastern part of Sabah, East Malaysia [35] and these are interpreted to reflect the obduction of an old oceanic crust of a Proto-South China Sea or of the Celebes Sea [1,17]. Several strike-slip faults cut through the island and some of these structures continue offshore (Figure 2). Some of the prominent faults that have been previously mapped are: Adang fault, Lupar Line, Tatau Mersing Line, Tinjar Line, Baram Line, and Long Aran Witti Kinaya fault $[14,28,30]$. Out of these, the $\sim N N E-S S W$ trending Aran Witti Kinaya fault (AWKF) is the major structure that shows the abrupt truncation of geological units, and it also cuts through an array of strike-slips faults (Figure 2). This suggests that the strike-slip faults are younger than the AWK fault. However, the bulk of these faults have not been mapped in any detail, including the AWK fault zone, and therefore, below, we provide firsthand information on the extent of faulting in central Borneo, how deformation is distributed on a regional scale, and what possibly controls it at depth.

\section{Instrumental Seismicity}

The available Instrumental earthquake data from the National Centers for Environmental Information (NCEI) and United States Geological Survey (USGS) Advanced National Seismic System are plotted on shaded relief images (Figure 1). The significant earthquakes and volcanoes are also plotted (Figure 1A), and this includes the June 2015 Ranau earthquake. The clustering of earthquake hypocenters around Borneo Island reflects the occurrence of major plate boundaries (Figure 1). The distribution of earthquakes on Borneo is scarce, with small clusters in and around NW portions. The available centroid moment tensor solutions of earthquakes largely show normal and strike-slip movement on fault planes (Figure 1B), and this suggests continuous movement on faults, which could mean that the region is undergoing oblique extension (see our results and discussion section). The earthquake data have not been corrected for depth and location, which means that there could be some errors in the horizontal and vertical locations of earthquake points. We have plotted the world population data on the satellite image and this highlights the pockets of dense population and their vulnerability to earthquake hazards and what type of faults are expected to contribute to the earthquake hazards (Figure 1B).

\section{Methodology}

Remote sensing techniques are very useful in the mapping of geologic, geomorphic, and landuse patterns [19,36-39]. Past studies have extensively demonstrated the strong applicability of satellite data in the mapping of active tectonic landforms. Such mapping becomes a very vigorous active fault mapping technique when combined with fault plane solutions, structural, geologic, and geodetic data [14,19-27]. Borneo Island is ornamented with a beautiful cover of lush green rain forest that makes it difficult to use high resolution Google images [17]. Therefore, we have extensively used the Google terrain mode where topographic features are easy to map. Our mapping uses standard 
procedures as outlined in the reference cited above. The various geomorphic features $[15,19,40-42]$ are identified, which include triangular facets, fault rupture scarps, topographic breaks, displaced ridge axes, deflected drainages, faulted young volcanic landforms, uplifted and back-tilted Holocene to Recent sedimentary deposits, and actively growing folds. We use geomorphic mapping to interpret the fault plane solutions which are created in a freely available structural geology software known as FaultKin 7 [43].

\section{Limitation of Google Maps}

The freely available Google satellite data are extensively used for research and other purposes primarily because it is free of cost, easy to use, and allows significant visualization and dissemination of scientific data [44-46]. However, its developers have disclosed limited accuracy information and descriptions of image processing methods involved, which remains a major obstacle [45] and that has not been studied thoroughly. Some studies have raised this concern and demonstrated that the vertical and horizontal accuracy of data from the Google Earth terrain mode, which uses SRTM (Shutter Radar Topographic Mission) elevation data, could be used in future remote sensing studies [44]. They have suggested that Google developers and the scientific community should work together to make the data more robust and transparent [44].

\section{Results and Interpretation}

\subsection{Tectonic Geomorphology}

A broad region of strike-slip faulting is mapped here (Figures 3-11), where distinctive drainage deflections are a characteristic feature of most of the region that is investigated (Figures 3-9 and Figure 11). Most of the rivers are deflected by faults, and these deflections often reflect both left and right lateral offset across faults; for example, Ranjang River shows this throughout (Figures 3 and 4). Broadly, two major fault trends are mapped, and these are $\sim \mathrm{NW}-\mathrm{SE}$ trending dextral strike-slip faults, and $\sim$ NE-SW to $\sim$ N-S trending sinistral strike-slip faults. The $\sim$ NW-SE trending dextral strike-slip faults have deflected streams and ridges and the stream offset varies from $<450 \mathrm{~m}$ to $>1700 \mathrm{~m}$, while the ridge offset varies from a few kilometers to $>5 \mathrm{~km}$ (Figures 3-9 and Figure 11).

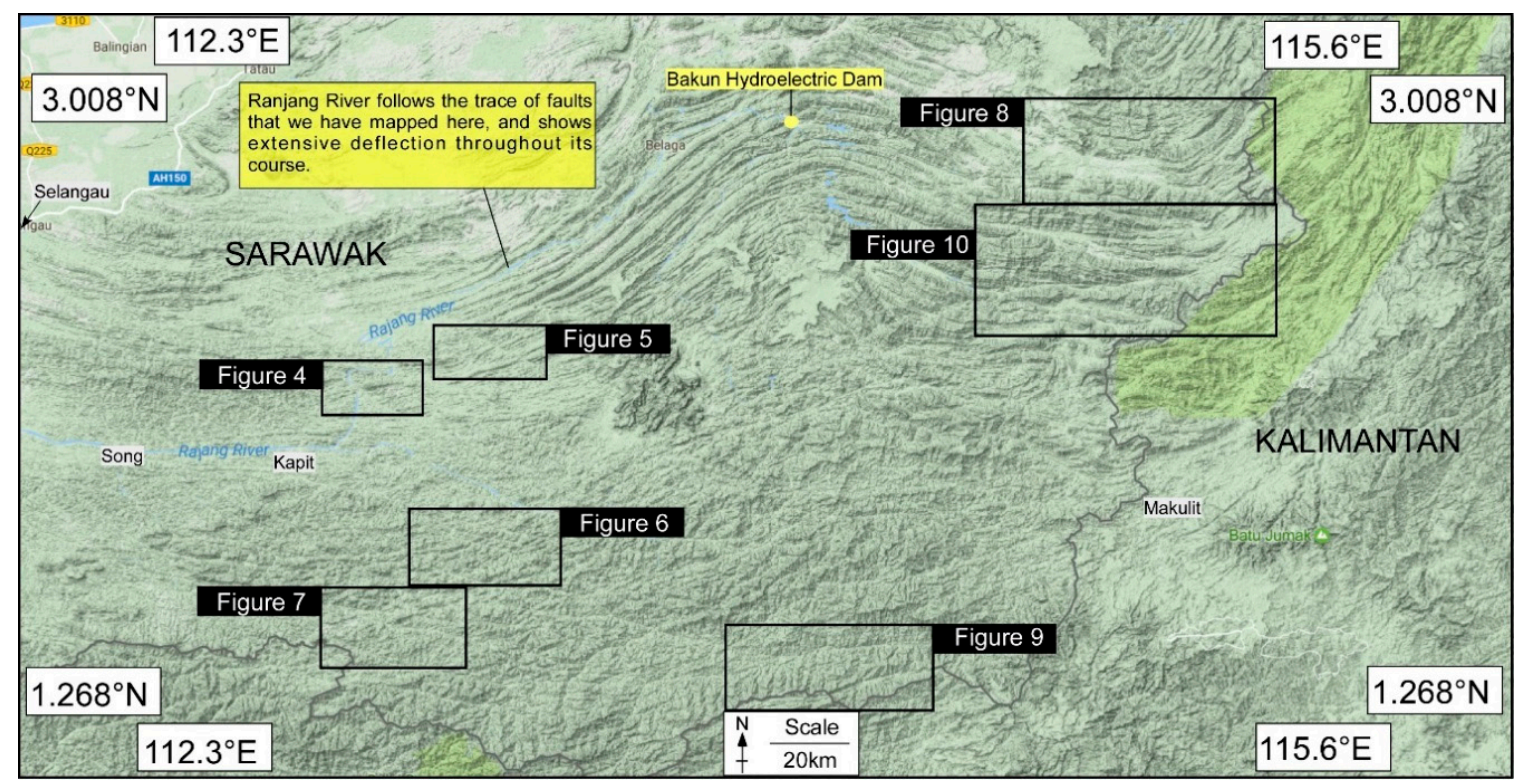

Figure 3. Google satellite terrain image shows the location of some of the selected regions in Borneo where faults have been mapped. The details are in subsequent figures. 
The deflection of rivers is not consistent throughout the length of the faults, and this may suggest a number of reactivation events along faults. The fault plane is either dipping $\sim$ NE or $\sim$ SW (Figure 4 ). The $\sim$ SW dipping fault plane is expected to host an earthquake with a minor amount of reverse slip. However, if the fault is $\sim$ NE dipping, then the expected earthquake will have a minor amount of normal slip along with the dextral strike-slip (Figure $4 \mathrm{D})$. We interpret the fault as $\sim$ NE dipping that has a normal component (Figure 4C,D).
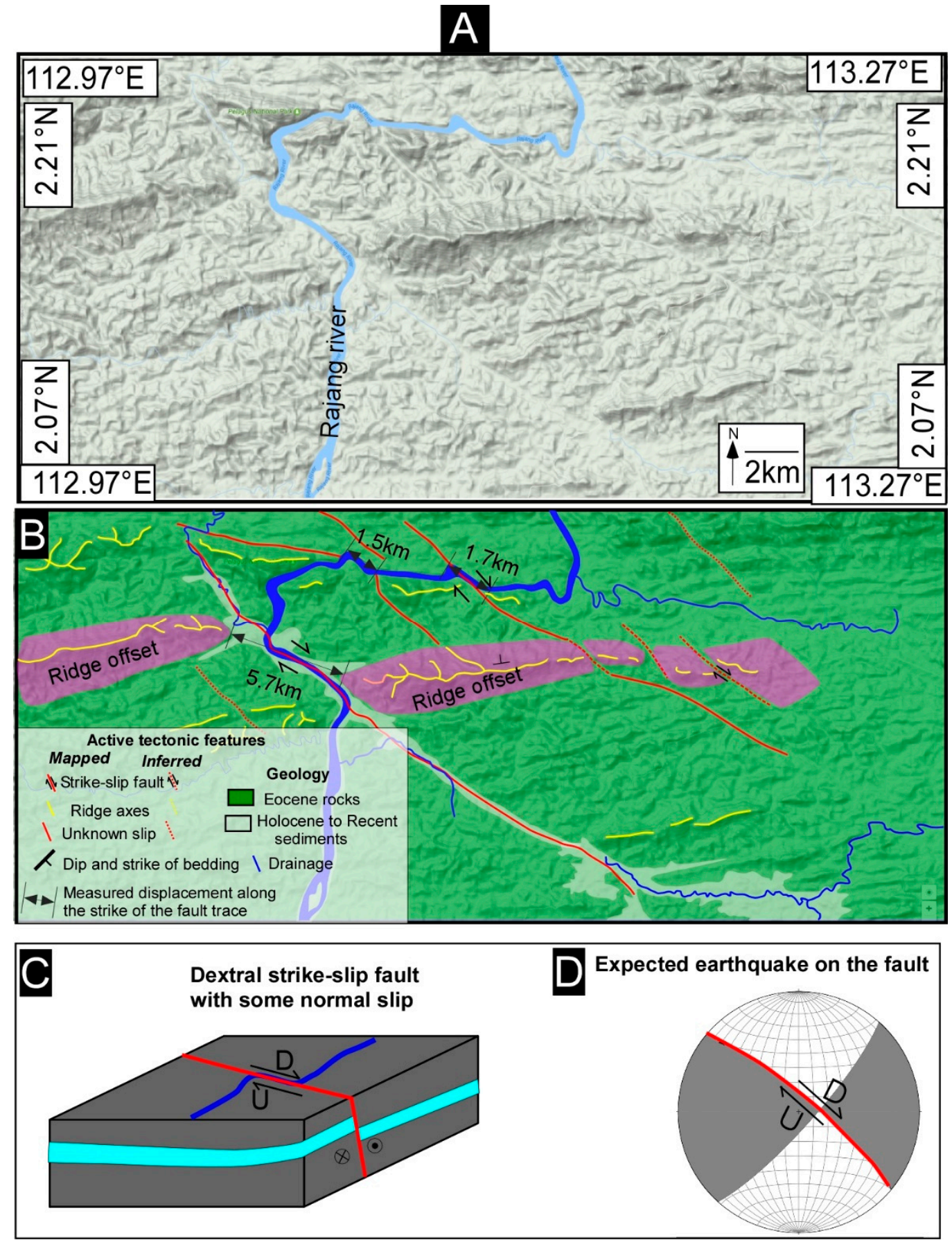

Figure 4. (A) Un-interpreted Google terrain image. (B) Evidence of dextral strike-slip faulting. (C) Cartoon shows the possible dip and dip direction of faulting. (D) The expected fault plane solution. The large river seems to have a sinistral offset but it is actually following the extent of dextral offset of the fault that cuts through the ridge for $\sim 5.7 \mathrm{~km}$. 
Additionally, our mapping and geomorphic expression of faulting throughout the region is more consistent with the $\sim$ NE dipping fault plane (Figure $4 \mathrm{D}$ ). The $\sim$ NW-SE trending dextral strike-slip faulting is clearly shown by the $\sim 1 \mathrm{~km}$ offset of the ridge axis (Figure 5). The sinistral strike-slip faults are not clearly visible in this portion but become clearly traceable further east (Figures 5-11).
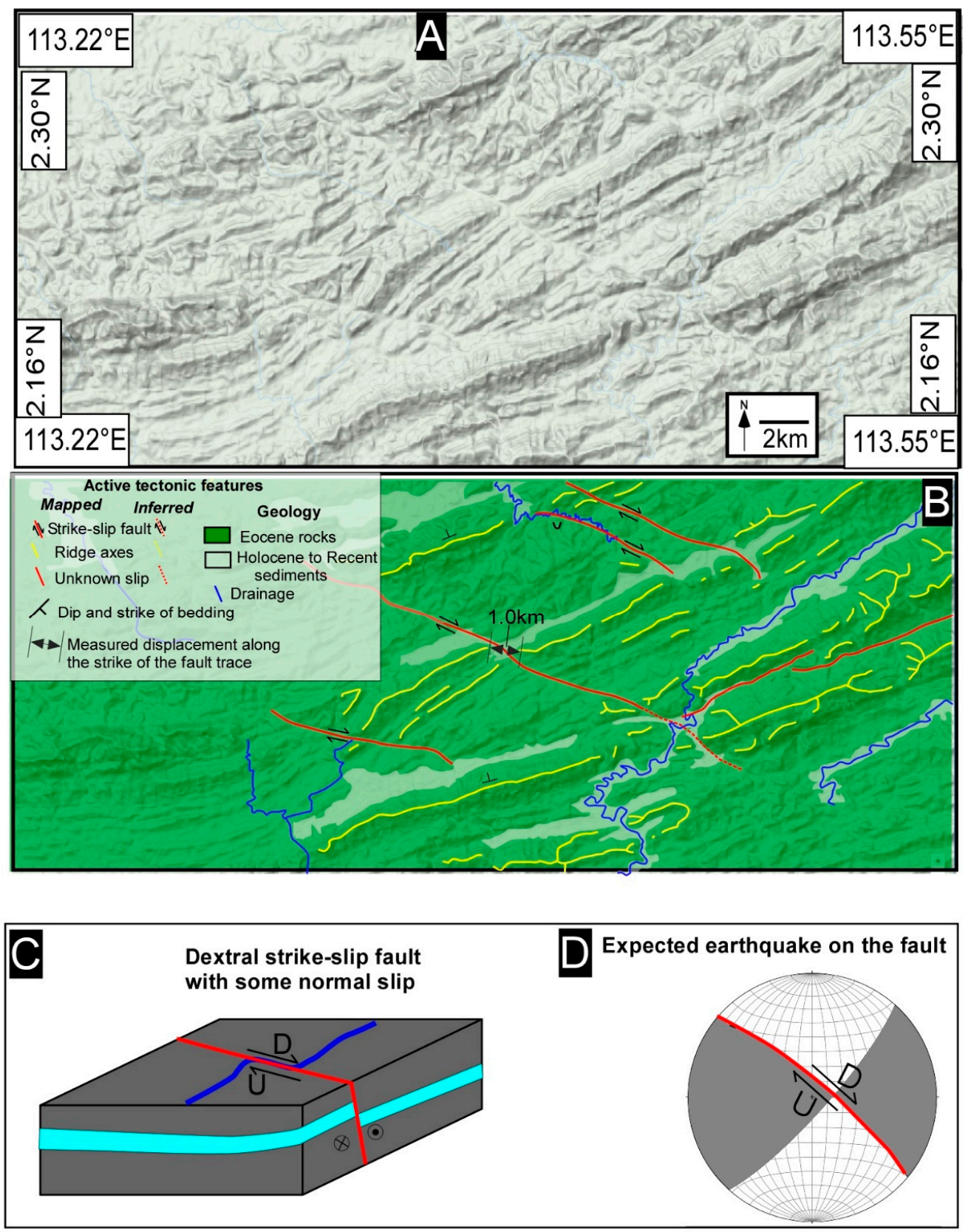

Figure 5. (A) Un-interpreted Google terrain satellite image. (B) Example of clear dextral strike-slip faulting, and poorly developed nature of sinistral strike-slip faulting in this region. (C) Cartoon shows the possible dip and dip direction of faulting. (D) The expected fault plane solution.

The two major trends of the mapped faults interact and form characteristic rhomb-shaped landforms (Figure $6 \mathrm{~B}$ ). The dextral strike-slip faults offset $\sim$ NE-SW trending sinistral strike-slip faults, and this seems to suggest a relatively younger age. The sinistral strike-slip fault dips either $\sim \mathrm{NW}$ or $\sim \mathrm{SE}$ (Figure 6C,D). 

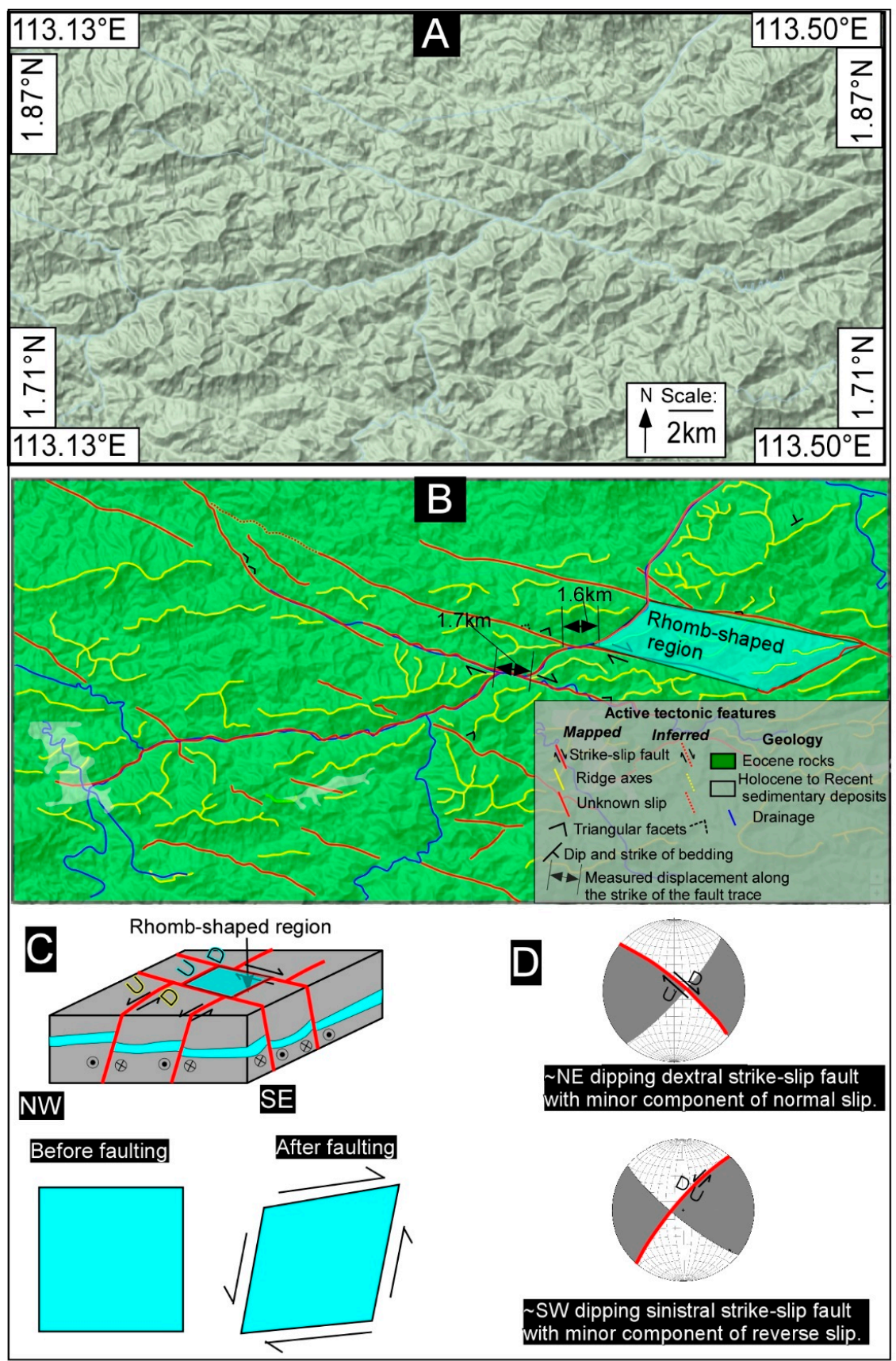

Figure 6. (A) Un-interpreted Google satellite image. (B) Shows evidence of Rhomb-shaped landforms that are directly related to strike-slip faulting. (C) Cartoon shows the possible nature of faulting where dextral-strike slip faults have a component of normal dip-slip and sinistral faults have a component of reverse slip. Also shown are the expected earthquakes on these faults (D).

Our mapping and geomorphic expression of faulting, however, is more consistent with a NW dipping fault plane with a minor amount of reverse slip (Figure 6). This is mainly based on the topographic expression of faulting and the presence of $\sim \mathrm{SE}$ facing triangular facets (Figure 6). The overall pattern of faulting via geomorphic landforms becomes clear and obvious further east (Figures 7-11), where geomorphic expression of thrusting is clearly visible for hundreds of kilometers (Figures 3-11). 

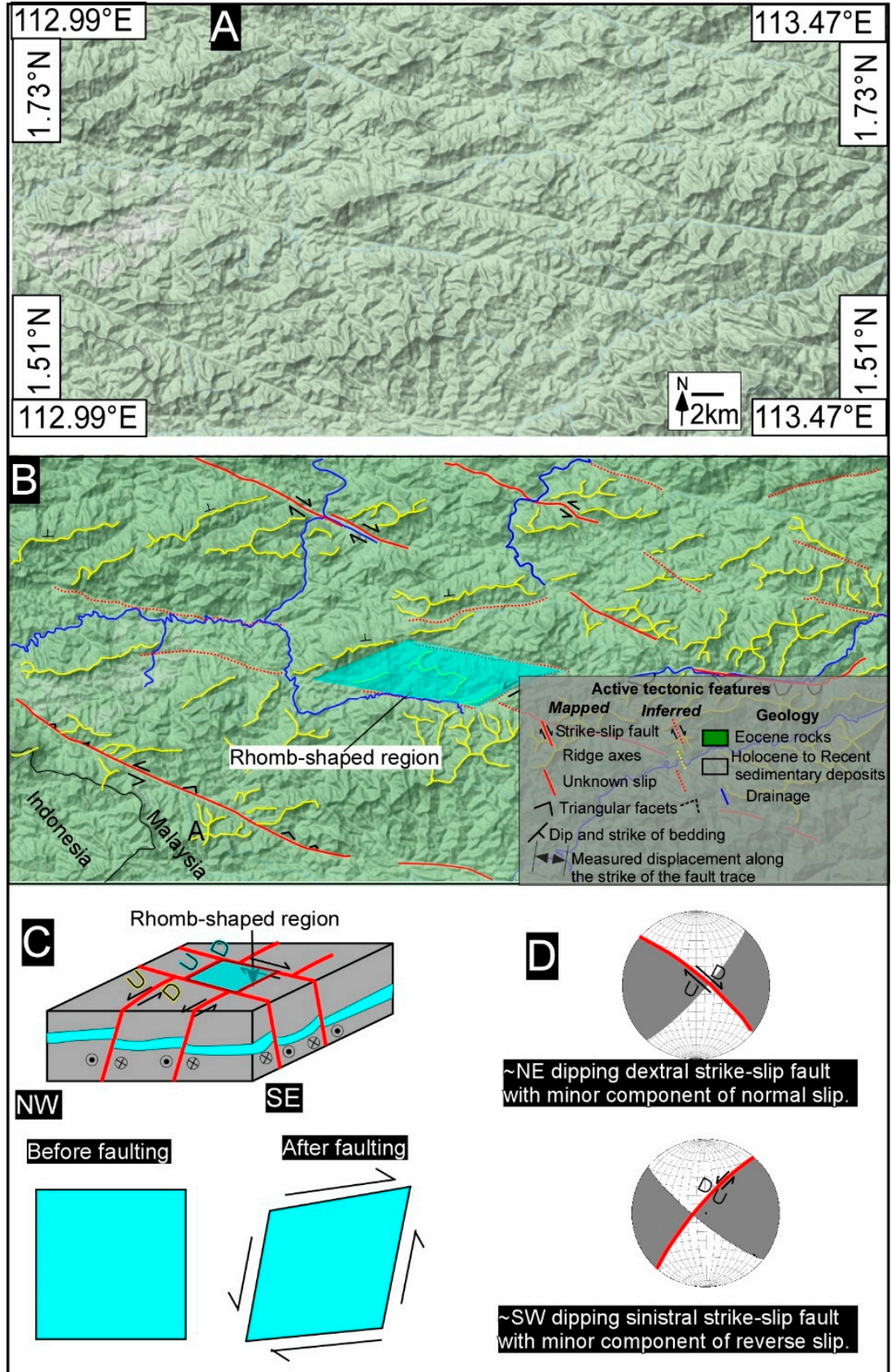

SW dipping sinistral strike-slip fault with minor component of reverse slip.

Figure 7. (A) Un-interpreted Google terrain image. (B) Evidence of not so well developed Rhomb-shaped landforms that are directly related to strike-slip faulting. The disrupted topography is clearly visible. (C) Cartoon shows the possible nature of faulting where dextral-strike slip faults have a component of normal dip-slip and sinistral faults have a component of reverse slip. Also shown are the expected earthquakes on these faults (D).

It seems that the slip along the mapped faults is more oblique towards the Eastern central part where folding is also common (Figures 3-11). The sedimentary beds are clearly truncated by the fault (Figure 10), and the ridges are completely broken and preserve evidence of sinistral shear. The faults seem to originate from the main trunk of the major sinistral fault system that possibly originates from Sabah, Malaysia, and forms a fanning pattern of faulting. A variety of geomorphic features are visible throughout the extent of the fault, and this includes enéchelon ridges that clearly show the sinistral shear on them. 

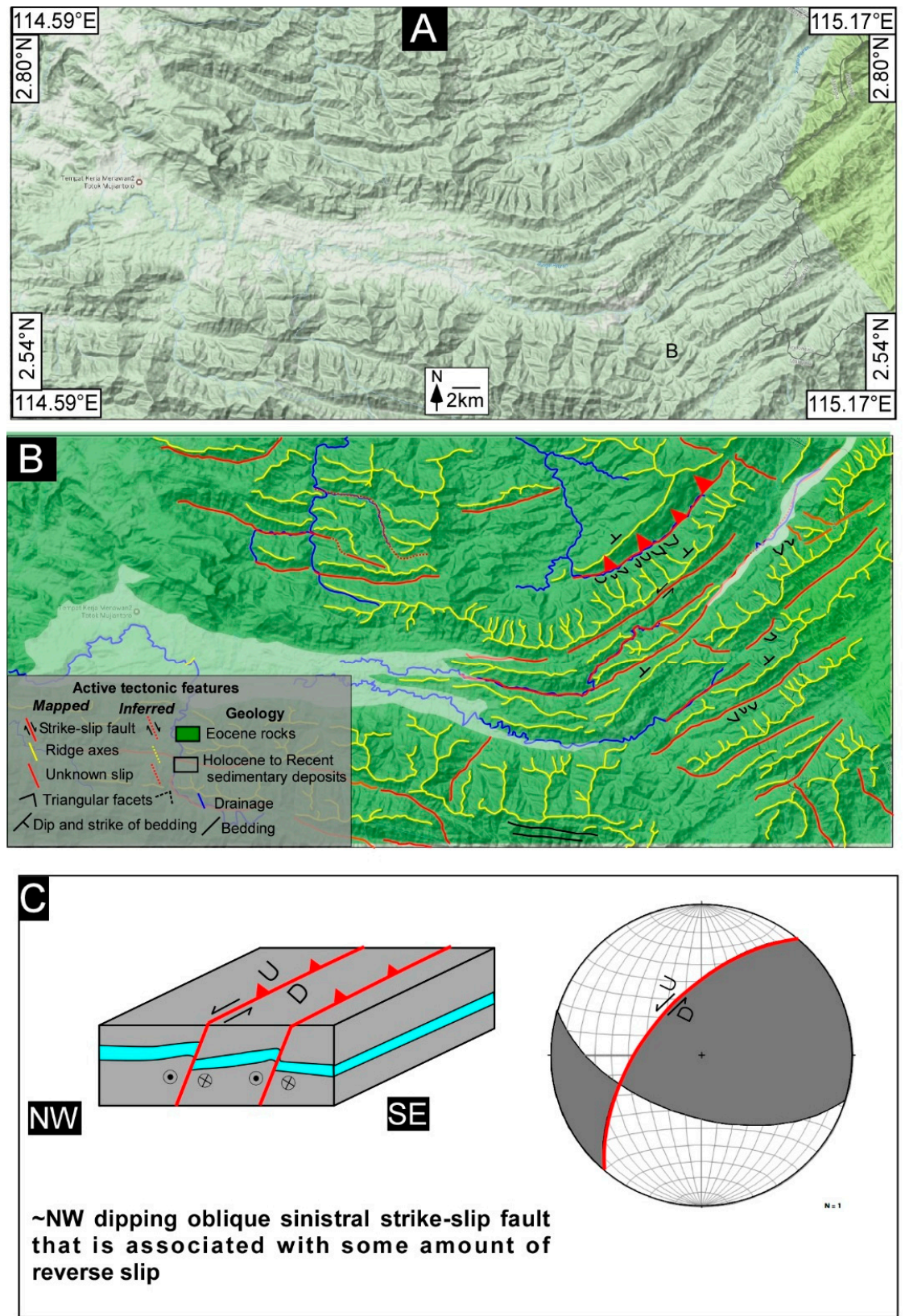

Figure 8. (A) Un-interpreted Google terrain image. (B) Shows evidence of $\sim$ NW dipping thrust faults, and strike-slip faulting. The prominently developed triangular facts have carved rock beds that $\sim$ dip NW, and only $\sim$ NW dipping beds are clearly visible. (C) Cartoon shows the possible nature of faulting where sinistral faults have a component of reverse slip. Also shown are the expected earthquakes on these faults.

The lack of high resolution data and the presence of thick forest cover has hindered our detailed mapping where we could have measured the deformed fluvial landforms in much more detail; for example, uplifted river terraces or any other young geomorphic landforms. Currently, we are in the process of acquiring the Malaysian government's permission to visit some of these regions to undertake a comprehensive geological field operation. However, with these limitations in mind, we have mapped and produced a map of faulting where various geomorphic landforms are mapped on a regional scale. This is the first large-scale map which shows the extent of faulting on a regional scale in Borneo. 

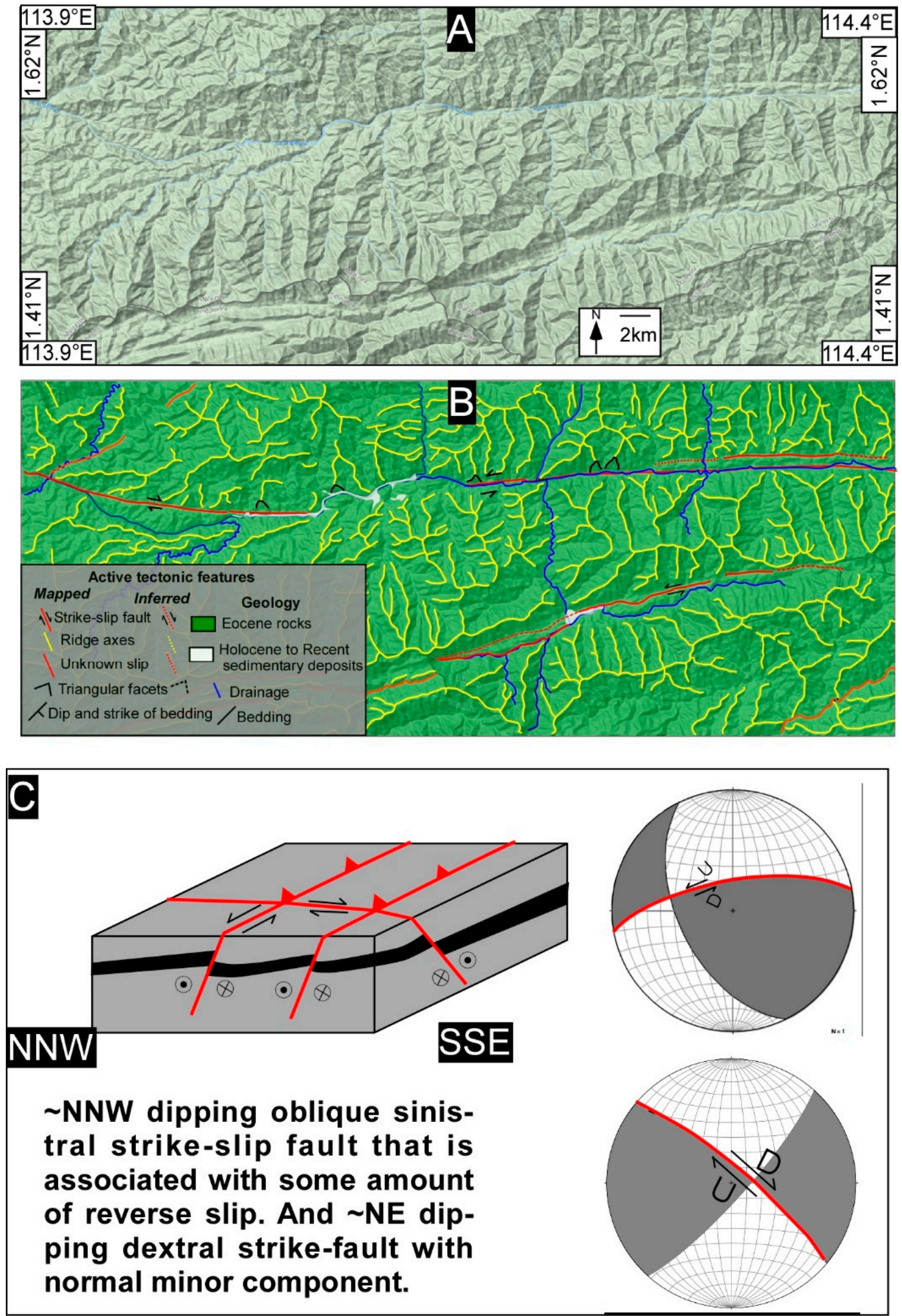

Figure 9. (A) Un-interpreted Google satellite image. (B) Evidence of clearly visible strike-slip faulting with two prominent traces that run oblique to each other. The topographic breaks, triangular facets, and drainage deflections are clearly traceable. (C) Cartoon shows the possible nature of faulting where dextral-strike slip faults have a component of normal dip-slip and sinistral faults have a component of reverse slip. The expected fault plane solution is also shown. 

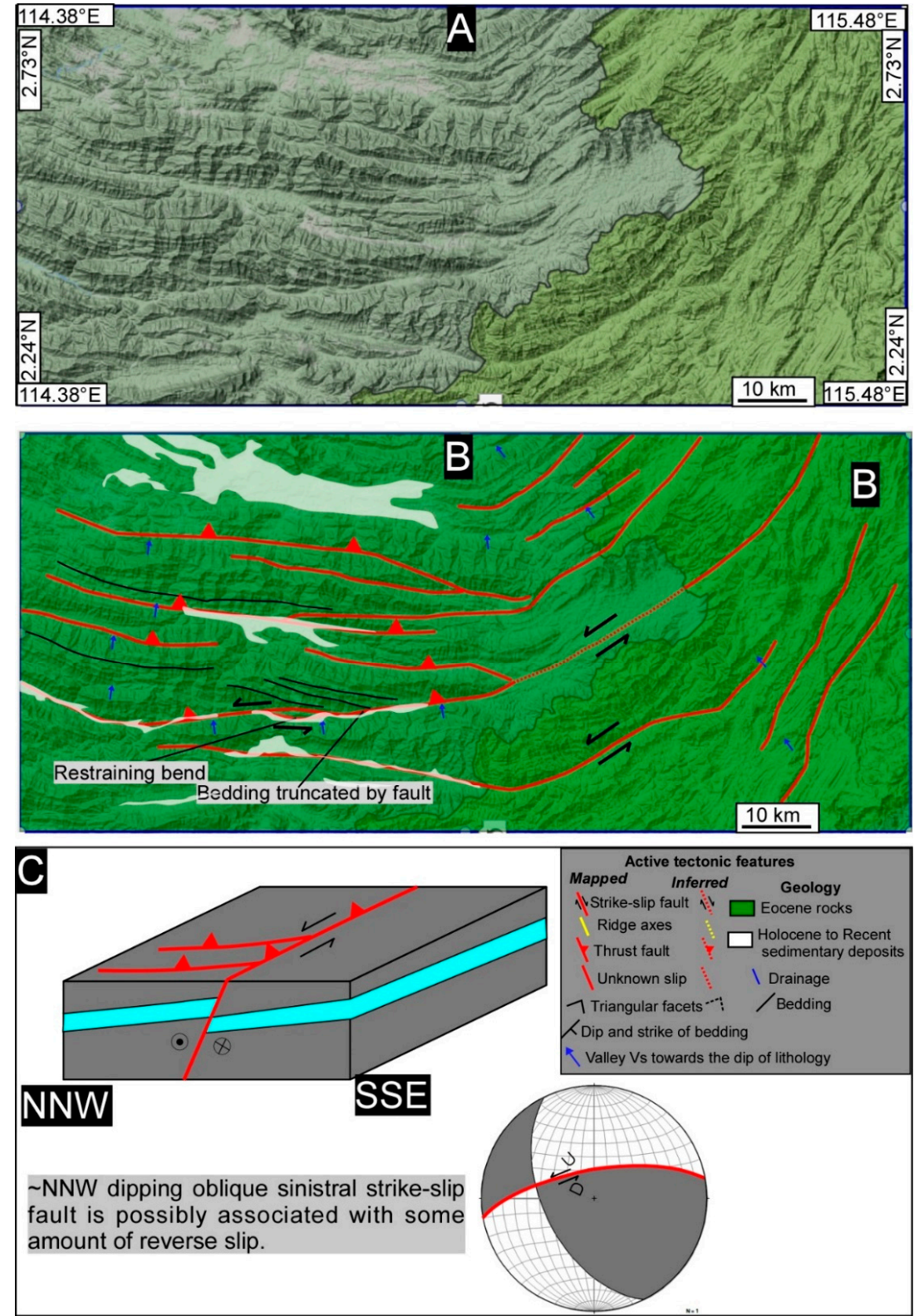

Figure 10. (A) Un-interpreted Google terrain image and (B) shows interpreted image. The evidence of truncated sedimentary beds by a major sinistral strike-slip fault where material is transported from $\sim$ north to $\sim$ south. The folding indicates a possible fault-bend fold geometry at depth, and a component of reverse slip along with strike-slip faulting. The reverse faults are fanning at the fault tip of the major fault, which indicates compression with strike-slip. (C) The expected fault plane solution and the associated cartoon show the possible nature of faulting where sinistral strike-slip faults have a component of reverse slip.

The mapped faults shown here clearly suggest that some of the faults have pierced through Holocene to Recent sedimentary deposits (e.g., Figure 11); however, we strongly feel that a detailed geological field investigation is required to exactly measure the extent of any recent activity along these faults. The geologically recent offset along the smaller streams is hard to measure from the available satellite images, and this is one of the major hurdles in mapping of the active nature of faulting in Borneo (e.g., Figure 11). The instrumental earthquake data suggest that some of the faults are active (Figure 1) and this includes a few strike-slip events around the study area (Figure 1B). 
However, the lack of typical seismicity associated with an active orogen and the absence of larger topographic, geomorphic, or stream offset could suggest that most of the faults are inactive in the central portion of the island, are having large recurrence intervals, or are slowly slipping. But the presence of Plio-Pleistocene volcanic deposits that are cut by the fault system in eastern portions of the island (Figure 11) clearly show the active nature of faulting, thus demanding work on the ground.
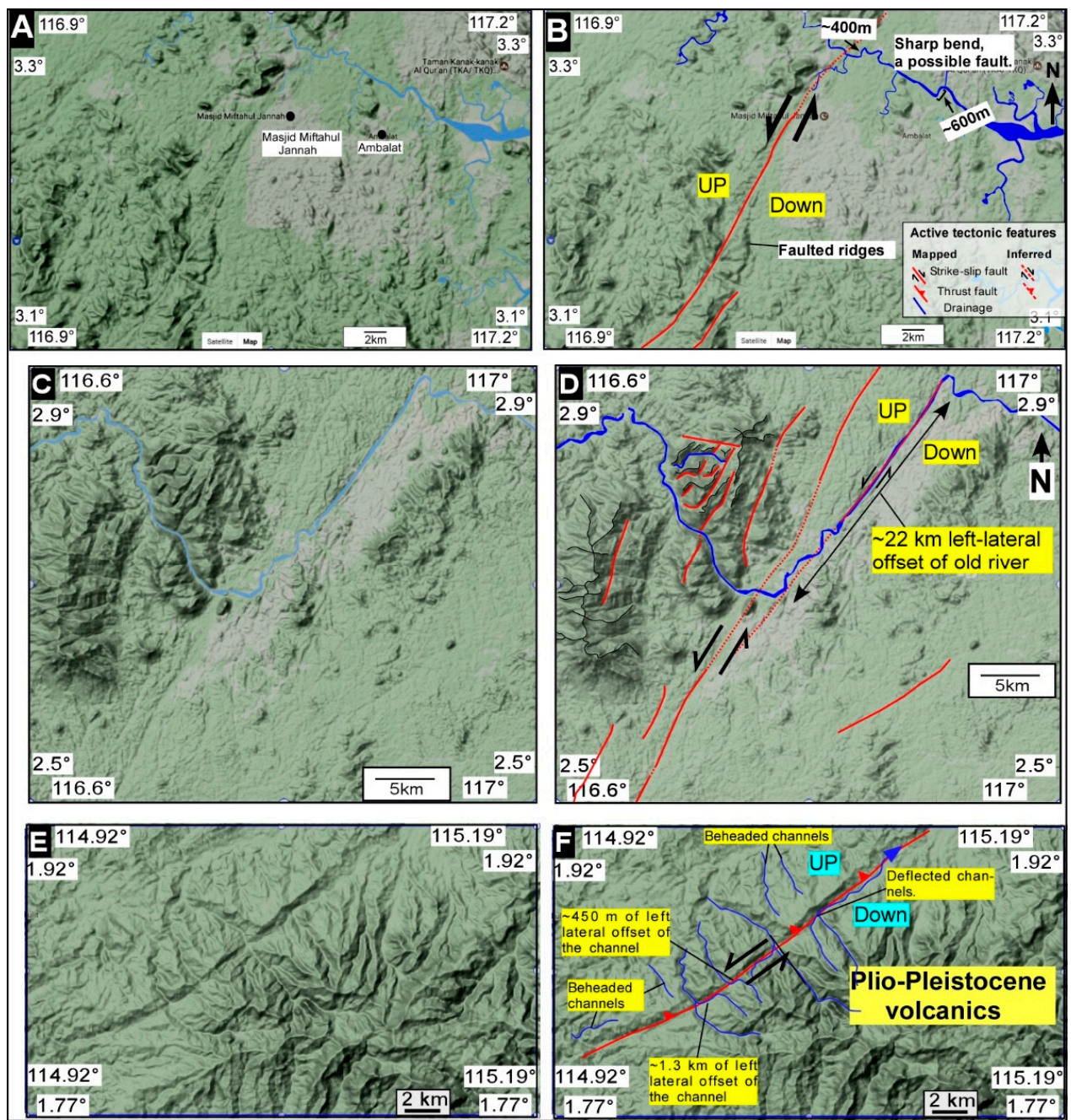

Figure 11. Un-interpreted Google terrain images are shown on the left and interpreted on the right. Clear evidence of left-lateral strike-slip offset along channels is widespread. (A) One such example where river channels are offset, and the fault cuts through the river and causes its deflection (B). Similarly the river channels and ridges are pierced by faults $(\mathbf{C})$, and the offset is quite large $(\sim 22 \mathrm{~km})$ (D). The Plio-Pleistocene volcanic deposits (E) are cut by faulting (F), and this indicate neotectonic movements along the mapped left-lateral strike-slip fault system.

Furthermore, our geomorphic mapping of landforms reveals that the fluvial channel patterns have been extensively modified by the two major strike-slip fault trends and such changes are obvious throughout the region (Figures 3-12). This has formed a unique crisscrossing geomorphic landscape of Borneo as most of the streams follow the two trends of the major fault systems (Figures 4-9). The $\sim$ straight river valleys are carved along faults and different slip on faults throughout the geological history of these valleys have produced zigzag patterns. Interestingly, the Bakun Hydroelectric Dam is one of the largest dams in the region and is capable of providing power supply not only to Sarawak, but also to neighboring countries such as Brunei and Kalimantan, Indonesia. The Dam sits on faults 
(Figure 3), and ideally the water load can impose stress on the faults; however, the quantification of strain and whether the water load has the potential to reactivate some of the faults via induced seismicity remains to be investigated, and such a topic is beyond the scope of the present regional mapping work. The clear evidence of left lateral strike-slip faulting is prominent in the eastern portion of the study area (Figure 11). The slip on the fault varies from $\sim 22 \mathrm{~km}$ to $\sim 450 \mathrm{~m}$. The large left-lateral offset recorded by the river (Figure 11D) is measured on the Google image. The river follows the strike of the fault, which is clearly visible. The fault has a small component of oblique slip, which is shown by the occurrence of uplifted and subsided regions (Figure 11). Additionally, based on the geomorphic expression of faulting, we think the fault is dipping $\sim \mathrm{NW}$, and thus it is has a component of thrusting with strike-slip. However, we are not sure about the recent movement on the fault at this region because although the river is clearly deflected and consistent with left-lateral offset, we are unable to find the smaller offset along the younger streams. So, it is possible that the large offset is not related to the actual fault slip, but the river has followed the trace of the fault. However, further southwest, the recent evidence of faulting is very clear and convincing (Figure 11F). This puts a strong constrain on the timing of the fault system because the Plio-Pleistocene volcanic deposits are cut by the fault, thus suggesting the active nature of faulting (Figure 11F).

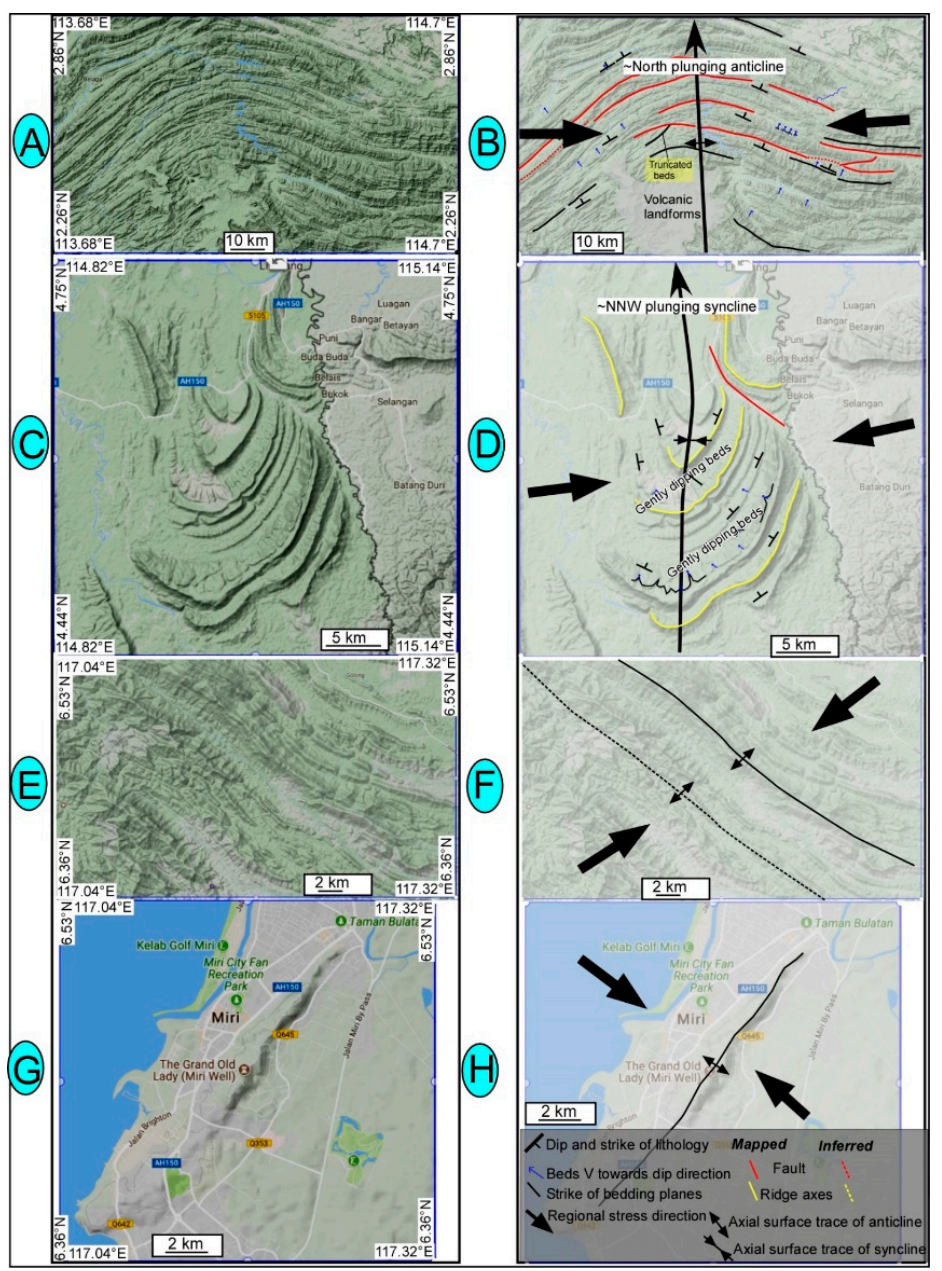

Figure 12. Un-interpreted Google satellite terrain images are shown on the left and evidence of folding is shown on the right. Broadly, two major folding events are recorded by the folded rocks, and these are associated with $\sim$ NNW-SSE (A-D) to $\sim$ NW-SE $(\mathbf{E}, \mathbf{F})$ and $\sim$ NE-SW $(\mathbf{G}, \mathbf{H})$ trending fold axes. Some of the folds are truncated by faults and are plunging $\sim$ northward $(\mathbf{B}, \mathbf{D})$. Examples of $\sim$ NW-SE $(\mathbf{E}, \mathbf{F})$ and $\sim \mathrm{NE}-\mathrm{SW}(\mathbf{G}, \mathbf{H})$ trending fold axes that are controlled by faulting. 


\subsection{Regional Folding}

Three fold systems have been detected based on different trends of the fold axes: NNW-SSE, NW-SE, and NE-SW (Figure 12). The $\sim$ NNW-SSE trending fold axes (Figure 12A,B) are marked based on the changing dip direction of the sedimentary beds, and the folds are plunging towards north. A series of faults are also folded, and these faults are mostly thrust faults, and the sedimentary beds are clearly truncated by the fault system where the folding seems to have initiated (Figures 3 and 8 , Figures 9 and 10). The presence of truncated beds confirms that faults merge with the master fault at depth, on which most of the deformation is concentrated (see below). Throughout the region, the mapped folds (Figure 12) seem to have developed simultaneously with faults.

\section{Discussion}

\subsection{Tectonic Geomorphology and Fault Controlled River Patterns of Borneo}

Our study area falls south of the Baram line, and further south of the Tinjar line [29,30]. These "lines" are considered regional faults zones, but the geomorphic evidence of faulting onshore is lacking $[17,30]$, and therefore our work is the first attempt to map the onshore equivalent of these lines and similar structures to understand their nature and significance on a tectonic scale. The faulted landforms that we have mapped (Figures 3-11), together with the seismological data, show that this region has experienced oblique compression (shown by strike-slip faulting), and that is still active today. The pervasive nature of $\sim$ NE dipping dextral and $\sim$ NW dipping sinistral strike-slip faulting is a clear indicator that this region is undergoing oblique compression that possibly originates from the current $\sim$ NW-SE directed horizontal forces, which may be associated with the active compression along the Palawan trough or elsewhere (Figure 2). The characteristic river deflections, drainage patterns, and topographic breaks are some of the key elements of tectonic geomorphology that we have mapped here. Previous works have shown that crustal deformation and landscape patterns are linked via tectono-geomorphology and various geomorphic features, for example, topographic breaks, escarpments, discontinuities, and changes along river courses and drainages $[41,42,47]$. This is particularly true for rivers, which are very sensitive indicators of changes that can be tectonic or climatic in origin $[41,47,48]$. Thus, rivers are very crucial tools to map and estimate the tectonic adjustments that a region has witnessed over the geological timescale [41,42,47,48]. The strike-slip faults mapped in this study have literally caused some of the rivers of Borneo Island to form distinctive zigzag patterns and such deflections are nicely preserved by older rivers, and Rajang River is one such spectacular example (Figures 3 and 4 ) of that. The curvilinear path carved by the river is witness to the continuous movement on the faults that this river follows. It is not an antecedent river and instead it is directly controlled by the faulting pattern in Borneo. An initial examination of the offset along the river seems to suggest a sinistral offset, but in reality, the river follows the extent of dextral offset of the fault that cuts through the ridge system for $\sim 5.7 \mathrm{~km}$ (Figure 4). Thus, the remarkable faulted landforms that we have mapped herein show some evidence of Holocene to Recent activity and this makes it a characteristic feature of intra-plate faulting. The ubiquitous occurrence of faulted landforms and the large extent of faulting suggest a tectonic origin.

\subsection{Strike-Slip Faults Are Related to Plate Tectonic Forces}

Our mapped dextral and sinistral strike-slip faults are clearly developed in the central and eastern portions of Borneo and have cut through the folded sedimentary sequences for $>230 \mathrm{~km}$, and preserve evidence of recent movement where some faults cut through Plio-Pleistocene volcanic deposits (Figure 11). The $\sim$ NW dipping sinistral strike-slip fault system (Figures $6-11$ ) has either developed simultaneously with the dextral system as conjugate faults, or has formed after the event that led to the formation of the dextral fault system. The fact that (Figure $6 \mathrm{~B}$ ) NW-SE oriented dextral faults displace the $\sim$ NE-SW oriented sinistral faults shows that sinistral faults are relatively older or that these faults are slowly slipping. 
The presence of regional folds (Figures 1 and 12) and the widespread occurrence of strike-slip fault systems leads us to interpret Borneo Island as a classic example of oblique convergence where strike-slip faulting is accompanied by a small component of dip-slip movement. The lack of larger-scale slip on both the dextral and the sinistral fault systems suggests that such faults could be related to local or regional forces but are not possibly linked to large scale tectonic structures [30]. However, it seems that the extrusion tectonic model [49] is applicable to Borneo because such a model argues that dextral faults are expected in Borneo as a continuation of escape tectonic structures on which most of Asia has been transported [50] and it continues today. Thus, our mapping suggests that the strike-slip fault system with two polarities that we have mapped in Borneo should either be related to the regional tectonics or to the extrusion tectonic of SE Asia. We strongly feel that non-tectonic forces may not produce the scale of faulting that we have mapped above.

Further, the faults that we have mapped show a pattern that resembles a larger curvilinear sinistral-slip fault that should run through the backbone of the island, and could shoulder most of the deformation that we have mapped above. The presence of a larger plunging fold (Figure 12B) suggests a strong structural control, and possibly indicates a fault-bend-fold geometry at depth. This is further justified by the presence of truncations where sedimentary beds are clearly truncated by the major fault that possibly originates in Sabah, Malaysia, and runs for $>900 \mathrm{~km}$ throughout the extent of the island (Figure 13). This major fault is possibly responsible for the June 2015 and March 2018 earthquakes in Sabah that occurred on a NW dipping normal fault (Figure 13D). The June 2015 earthquake has generated a lot of interest in understanding the cause of deformation in the region [15]. The occurrence of normal fault-related earthquakes in Sabah (Figure 13) suggests extension, and what exactly is causing this extension remains unclear (e.g., [15]). Previous models (Figure 13) have either attributed the active deformation to gravitational forces or tectonic forces, or both [15,51-54]. The fact that active fold and a thrust belt exist and are growing offshore Sabah indicates $\sim$ NW-SW directed crustal shortening, and similar structures exist onshore that indicate $\sim \mathrm{NW}-\mathrm{SE}$ directed extension. This could be explained by a large gravitational slide, which brings material from onshore Sabah via normal faulting, and piles it up on offshore structures via thrusting (e.g., [51,53]). This requires a large-scale décollement, which could be shale under pressure, onto which material could be transported. The major problem with this model is the fact that that normal faulting earthquake events (Figure 13A) with $\sim$ NW dipping fault plane mean that the Mt. Kinabalu Granite is actively subsiding because it lies on the hanging wall block of the Crocker fault system that generated the Mt. Kinabalu earthquake in 2015 (Figure 13). However, past geological studies have suggested that Mt. Kinabalu Granite has been exhumed since its crystallization some 5-6 Ma [54]. Similarly, the hypocentral depth of two earthquake events that occurred in Sabah (Figure 13D) ranges from 13 to $10 \mathrm{~km}$. These structural details are difficult to explain simply by gravitational collapse (e.g., [15]). Similarly, neither the basement involving the shortening model nor the localized stress model is able to explain the extent and scale of faulting that we have mapped (Figure 13). The fault mapped by us (e.g., [15,55]) is instead arguably evidence of a major sinistral strike-slip fault system that might explain the existence of extension in NW Borneo, and this could be responsible for the large scale pattern of faulting that is mapped in Borneo, and therefore, we propose that the tectonic forces are largely responsible for deformation in Borneo that $\sim \mathrm{NW}$-SE directed regional oblique compression is driving the deformation seen in Borneo (Figures 13 and 14). Our work suggests that the deformation in Borneo Island is strongly controlled at depth by a major structure that we think is a large scale sinistral strike-slip fault. Such a major structure possibly originates in Sabah and perhaps extends further north. The fault resembles a typical major sinistral strike-slip fault that has created a tectonic topography where the central portion of the fault zone is relatively straight and forms an array of enéchelon ridges (Figures 13 and 14), and prominently developed horsetails at the tips of the major fault. The patterns of folding, faulting, and the overall topography are consistent with the major sinistral fault that runs through the center of the island (Figure 14). Thus, we strongly argue, based on geomorphic mapping (shown above), that the topographic expression of the island and 
its structural framework are tectonically controlled, which can be explained by oblique convergence (Figure 14).

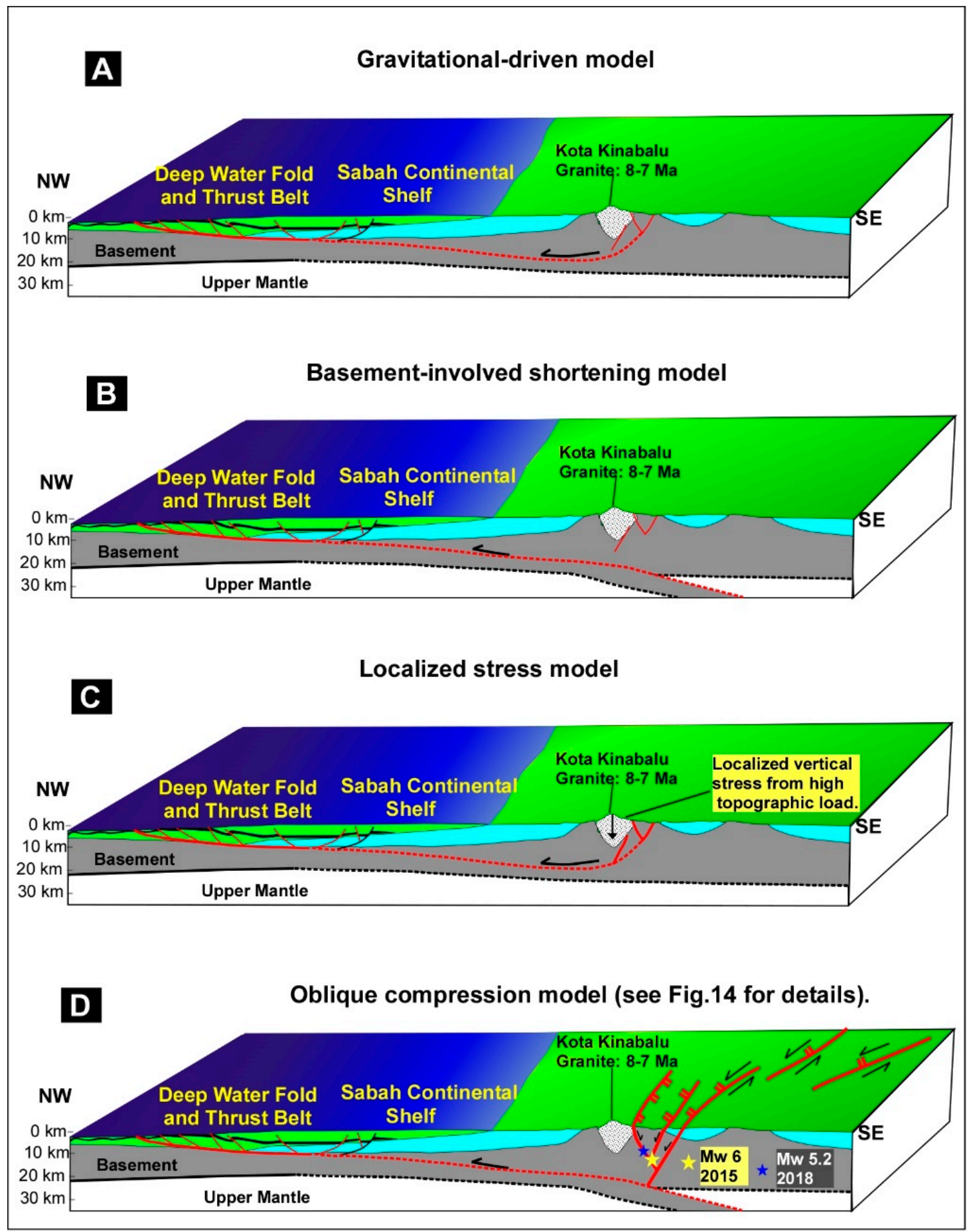

Figure 13. (A) Gravitational model in which faulting in NW Borneo is associated with vertical forces (gravity). (B) Another model involving basement shortening where thrusts verge towards $\sim \mathrm{NW}$ and are linked to horizontal forces related to plate tectonics. (C) Localized stress model in which faulting is associated with vertical forces due to granite (modified after [15]). (D) Oblique compression model from our study. The figure is modified after [15]. 

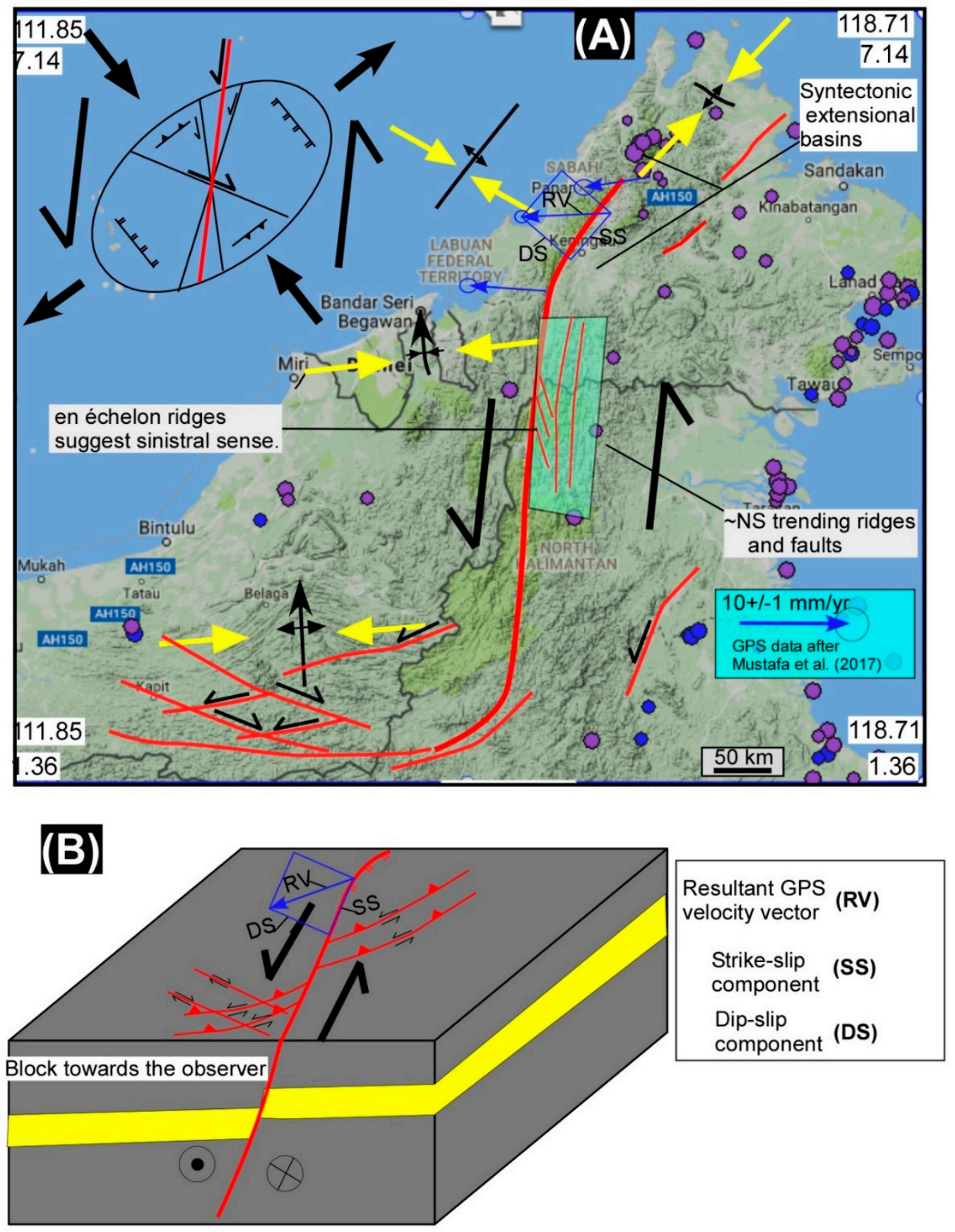

Figure 14. (A) Shows a tectonic model for the formation of structures that are mapped herein. A large sinistral fault that runs $\sim$ through the center of Borneo Island could possibly explain the observed topography, geomorphology, structures, and geology of the region. The oblique convergence model fits well with the mapped and observed structures (B), and strongly backs a tectonic origin rather than a purely gravity driven deformation. The recent GPS data supplement this model.

\section{Conclusions}

The strike-slip fault systems mapped here are on land confirmation that regional stresses in Borneo are oblique with respect to the main trend of the Crocker Rang and this is manifested in topography, where several strike-slip faults have formed over the geological history of the region, and some of these faults are still active (this study). Our data provide the first geomorphic evidence 
of large-scale faulted landforms that are mostly located south of the previously mapped faults zone including the Baram Line and Tinjar Line $[29,30]$. The mapped faults could be a continuation of these tectonic lines, and if that is the case, then this can be explained by the regional escape tectonic model for the formation of SE Asia [50]. The presence of small-scale offsets on mapped faults means that such faults are of local significance (e.g., [30]). However, our mapping suggests a strong structural control on the formation and deformation of Borneo. We argue that a central sinistral strike-slip fault is controlling most of the deformation seen on land, and the extent of structural and topographic expression of faulting is tectonically controlled. Additionally, mapped structures strongly indicate oblique regional convergence (Figures 13 and 14) with respect to the main trend of the Crocker Range that forms the backbone of Borneo Island.

Author Contributions: A.A.S., M.N.Z., J.D. and B.N. have jointly produced the maps that are published in the paper. A.A.S. was the leader of the project and his students M.N.Z. and J.D. have studied the satellite, seismological, and geological data to map the unknown faults in Borneo. A.A.S. has written most of the paper, and reprocessed most of the figures that are now published here. B.N. has contributed in plotting of geodetic data, and production of a few geomorphic maps. A.A.S. has taken a central role in conceptualization of this paper, and all other authors have contributed significantly in results, interpretations, and discussion sections of the paper plus revision of the manuscript, and have approved the submitted version.

Acknowledgments: The critical evaluation of this manuscript by reviewers and editors is highly appreciated. We also thank Miss Tracey McTague of Arizona University for help in English editing of the manuscript.

Conflicts of Interest: The authors declare no conflict of interest.

\section{References}

1. Hutchison, C.S. Geological Evolution of South-East Asia; Clarendon: Oxford, UK, 1989.

2. Tongkul, F. The geology of Northern Sabah, Malaysia: Its relationship to the opening of the South China Sea basin. Tectonophysics 1994, 235, 131-137. [CrossRef]

3. Hall, R. Reconstructing Cenozoic SE Asia. In Tectonic Evolution of SE Asia; Geological Society London Special Publication: London, UK, 1996; Volume 106, pp. 153-184.

4. Morley, C.K. A tectonic model for the Tertiary evolution of strike-slip faults and rift basins in SE Asia. Tectonophysics 2002, 347, 189-215. [CrossRef]

5. Hall, R.; Marco, W.A.; Hattum, V.; Spakman, W. Impact of India-Asia collision on SE Asia: The record in Borneo. Tectonophysics 2008, 451, 366-389. [CrossRef]

6. Morley, C.K.; King, R.; Hillis, R.; Tingay, M.; Backe, G. Deepwater fold and thrust belt classification, tectonics, structure and hydrocarbon prospectivity. Earth Sci. Rev. 2012, 104, 41-91. [CrossRef]

7. Morley, C.K. Late Cretaceouse-Early Palaeogene tectonic development of SE Asia. Earth Sci. Rev. 2012, 125, 37-75. [CrossRef]

8. Hutchison, C.S. Oroclines and paleomagnetism in Borneo and south-east Asia. Tectonophysics 2010, 496, 53-67. [CrossRef]

9. Hutchison, C.S. The north-west Borneo trough. Mar. Geol. 2010, 271, 32-43. [CrossRef]

10. Murphy, R.W. Southeast Asia reconstruction with a non-rotation Cenozoic Borneo. Geol. Soc. Malays. 1998, 42, 85-94.

11. Li, S.Z.; Santosh, M.; Jahn, B.M. Evolution of the Asian continent and its continental margins. J. Asian Earth Sci. 2012, 47, 1-4. [CrossRef]

12. Li, S.Z.; Santosh, M.; Zhao, G.C.; Zhang, G.W.; Jin, C. Intracontinental deformation in a frontier of super-convergence: A perspective on the tectonic milieu of the South China Block. J. Asian Earth Sci. 2012, 49, 313-329. [CrossRef]

13. Mathew, M.J.; Menier, D.; Siddiqui, N.; Kumar, S.G.; Authemayou, C. Active tectonic deformation along rejuvenated faults in tropical Borneo: Inferences obtained from tectonic-geomorphic evaluation. Geomorphology 2016, 267, 1-5. [CrossRef]

14. Wang, P.C.; Li, S.Z.; Guo, L.L.; Jiang, S.H.; Somerville, I.D.; Zhao, S.J.; Zhu, B.D.; Chen, J.; Dai, L.M.; Suo, Y.H.; et al. Mesozoic and Cenozoic accretionary orogenic processes in Borneo and their mechanisms. Geol. J. 2016, 51, 464-489. [CrossRef] 
15. Wang, Y.; Wei, S.; Wang, X.; Lindsey, E.O.; Tongkul, F.; Tapponnier, P.; Bradley, K.; Chan, C.; Hill, E.M.; Sieh, K. The 2015 M W 6.0 Mt. Kinabalu Earthquake: An Infrequent Fault Rupture within the Crocker Fault System of East Malaysia. Geosci. Lett. 2017, 4, 6. [CrossRef]

16. Grebby, S.; Tansey, K. Advances in Lithological and Structural Mapping Using Earth Observation Data. Geosciences. 2017. Available online: http://www.mdpi.com/journal/geosciences/special_issues/ Lithologica-Structural-Mapping (accessed on 4 May 2017).

17. Hall, R.; Breitfeld, T.H. Nature and demise of the Proto-South China Sea. Bull. Geol. Soc. Malays. 2017, 63, 61-76.

18. Shah, A.A. Understanding the recent Sabah Earthquake, and other seismogenic sources in North West Borneo. Sci. Malays. 2016, 12, 7-10.

19. Shah, A.A.; Malik, J.N. Four major unknown active faults identified, using satellite data, in India and Pakistan portions of NW Himalaya. Nat. Hazards 2017, 88, 845-1865. [CrossRef]

20. Tapponnier, P.; Molnar, P. Active faulting and tectonics in China. J. Geophys. Res. 1977, 82, $2905-2930$. [CrossRef]

21. Nakata, T. Active faults of the Himalaya of India and Nepal. Geol. Soc. Am. Spec. Publ. 1989, 232, $243-264$.

22. Sieh, K.; Natawidjaja, D. Neotectonics of the Sumatran fault, Indonesia. J. Geophys. Res. Solid Earth 2000, 105, 28295-28326. [CrossRef]

23. Malik, J.N.; Nakata, T. Active faults and related Late Quaternary deformation along the northwestern Himalayan Frontal Zone. India Annu. Geophys. 2003, 46, 917-936.

24. Shyu, J.B.H.; Sieh, K.; Chen, G.; Liu, C.S. Neotectonic architecture of Taiwan and its implications for future large earthquakes. J. Geophys. Res. Solid Earth 2005, 120. [CrossRef]

25. Taylor, M.; Yin, A. Active structures of the Himalayan-Tibetan orogen and their relationships to earthquake distribution, contemporary strain field, and Cenozoic volcanism. Geosphere 2009, 5, 199-214. [CrossRef]

26. Shah, A.A. Earthquake geology of the Kashmir Basin and its implication for large earthquakes. Int. J. Earth Sci. 2013, 102, 1957-1966. [CrossRef]

27. Malik, J.N.; Shah, A.A.; Naik, S.P.; Sahoo, S.; Okumura, K.; Patra, N.R. Active fault study along foothill zone of Kumaun Sub-Himalaya: Influence on landscape shaping and drainage evolution. Curr. Sci. 2014, 106, 229-236.

28. Hutchison, C.S. The 'Rajang Accretionary Prism' and 'Lupar Line' problem of Borneo. In Tectonic Evolution of Southeast Asia; Hall, R., Blundell, D.J., Eds.; Geological Society of London Special Publication: London, UK, 1996; Volume 106, pp. 247-261.

29. Hutchison, C.S. Geology of North-West Borneo; Elsevier: Amsterdam, The Netherlands, 2005; p. 421.

30. Cullen, A. Transverse segmentation of the Baram-Balabac Basin, NW Borneo: Refining the model of Borneo's tectonic evolution. Pet. Geosci. 2010, 16, 3-29. [CrossRef]

31. Hamilton, W. Tectonics of the Indonesian Region; Professional Paper; U.S. Geological Survey: Reston, VA, USA, 1979; Volume 345, pp. 1-23.

32. Sapin, F.; Pubellier, M.; Lahfid, A.; Janots, D.; Ringenbach, J.C. Onshore record of the subduction of a crustal salient: Example of the NW Borneo Wedge. Terra Nova 2012, 23, 232-240. [CrossRef]

33. Hall, R. Cenozoic geological and plate tectonic evolution of SE Asia and the SW Pacific: Computer-based reconstructions, model and animations. J. Asian Earth Sci. 2002, 20, 353-434. [CrossRef]

34. Fuller, M.; Ali, J.R.; Moss, S.J.; Frost, G.M.; Richter, B.; Mahfi, A. Paleomagnetism of Borneo. J. Asian Earth Sci. 1999, 17, 3-24. [CrossRef]

35. Omang, S.A.; Barber, A.J. Origin and tectonic significance of the metamorphic rocks associated with the Darvel Bay Ophiolite, Sabah, Malaysia. Geol. Soc. Spec. Publ. 1996, 106, 263-279. [CrossRef]

36. Bocco, G.; Mendoza, M.; Velázquez, A. Remote sensing and GIS-based regional geomorphological mapping-A tool for land use planning in developing countries. Geomorphology 2001, 39, 212-219. [CrossRef]

37. Gomez, C.; Delacourt, C.; Allemand, P.; Ledru, P.; Wackerle, R. Using ASTER remote sensing data set for geological mapping, in Namibia. Phys. Chem. Earth 2005, 30, 97-108. [CrossRef]

38. Lee, S. Application of logistic regression model and its validation for landslide susceptibility mapping using GIS and remote sensing data. Int. J. Remote Sens. 2005, 26, 1477-1491. [CrossRef]

39. Kumar, R. Flood hazard assessment of 2014 floods in Sonawari sub-district of Bandipore district (Jammu \& Kashmir): An application of geoinformatics. Remote Sens. Appl. Soc. Environ. 2016, 4, 188-203.

40. Yeats, R.S.; Sieh, K.; Allen, C.R. The Geology of Earthquakes; Oxford University Press: Beijing, China, 1997. 
41. Schumm, S.A. Alluvial river response to active tectonics. In Active Tectonics: Impact on Society; National Academy Press: Washington, DC, USA, 1986; pp. 80-95.

42. Burbank, D.W.; Anderson, R.S. Tectonic Geomorphology; Blackwell Science: Hoboken, NJ, USA, 2001 ; p. 274.

43. Marrett, R.A.; Allmendinger, R.W. Kinematic analysis of fault-slip data. J. Struct. Geol. 1990, 12, 973-986. [CrossRef]

44. Benker, S.C.; Langford, R.P.; Pavlis, T.L. Positional accuracy of the Google Earth terrain model derived from stratigraphic unconformities in the Big Bend region, Texas, USA. Geocarto Int. 2011, 26, 291-303. [CrossRef]

45. Potere, D. Horizontal position accuracy of Google Earth's high-resolution imagery archive. Sensors 2008, 8 , 7973-7981. [CrossRef] [PubMed]

46. Butler, D. The web-wide world. Nature 2006, 439, 776-779. [CrossRef] [PubMed]

47. Ouchi, S. Response of alluvial rivers to slow active tectonic movement. Geol. Soc. Am. 1985, 96, 504-515. [CrossRef]

48. Keller, E.A.; Pinter, N. Active Tectonics: Earthquakes, Uplift, and Landscape; Prentice-Hall: Upper Saddle River, NJ, USA, 1999; p. 338.

49. Replumaz, A.; Tapponnier, P. Reconstruction of the deformed collision zone between India and Asia by backward motion of lithospheric blocks. J. Geophys. Res. Solid Earth 2003, 108. [CrossRef]

50. Tapponnier, P.; Peltzer, G.; Le Dain, A.Y.; Armijo, R.; Cobbold, P. Propagating extrusion tectonics in Asia: New insights from simple experiments with plasticine. Geology 1982, 10, 612-616. [CrossRef]

51. Sandal, S.T. The Geology and Hydrocarbon Resources of Negara Brunei Darussalam; Brunei Shell Petroleum: Bandar Seri Begawan, Brunei, 1996; p. 243.

52. Hesse, S.; Back, S.; Franke, D. The deep-water fold-and-thrust belt offshore NW Borneo: Gravity-driven versus basement-driven shortening. Bull. Geol. Soc. Amst. 2009, 121, 939-953. [CrossRef]

53. Sapin, F.; Hermawan, I.; Pubellier, M.; Vigny, C.; Ringenbach, J.C. The recent convergence on the NW Borneo Wedge-A crustal-scale gravity gliding evidenced from GPS. Geophys. J. Int. 2013, 193, 549-556. [CrossRef]

54. Cottam, M.A.; Hall, R.; Sperber, C.; Kohn, B.P.; Forster, M.A.; Batt, G.E. Neogene rock uplift and erosion in northern Borneo: Evidence from the Kinabalu granite, Mount Kinabalu. J. Geol. Soc. 2013, 170, 805-816. [CrossRef]

55. Tongkul, F. Active tectonics in Sabah-seismicity and active faults. Bull. Geol. Soc. Malays. 2017, 64, 27-36. 